\title{
Quantifying the effect of forests on frequency and intensity of rockfalls
}

\author{
Christine Moos $^{1,4}$, Luuk Dorren ${ }^{1}$, and Markus Stoffel ${ }^{2,3}$ \\ ${ }^{1}$ Bern University of Applied Sciences, School of Agricultural, Forest and Food Science HAFL, \\ Länggasse 85, 3052 Zollikofen, Switzerland \\ ${ }^{2}$ Climatic Change and Climate Impacts, Institute for Environmental Science, University of Geneva, \\ 66 Bvd Carl Vogt, 1205 Geneva, Switzerland \\ ${ }^{3}$ Department of Earth Sciences, University of Geneva, rue des Maraîchers 13, 1205 Geneva, Switzerland \\ ${ }^{4}$ Institute of Geological Sciences, University of Bern, Baltzerstrasse 1+3, 3012, Bern, Switzerland \\ Correspondence to: Christine Moos (christine.moos@bfh.ch)
}

Received: 28 June 2016 - Discussion started: 1 July 2016

Revised: 24 January 2017 - Accepted: 1 February 2017 - Published: 28 February 2017

\begin{abstract}
Forests serve as a natural means of protection against small rockfalls. Due to their barrier effect, they reduce the intensity and the propagation probability of falling rocks and thus reduce the occurrence frequency of a rockfall event for a given element at risk. However, despite established knowledge on the protective effect of forests, they are generally neglected in quantitative rockfall risk analyses. Their inclusion in quantitative rockfall risk assessment would, however, be necessary to express their efficiency in monetary terms and to allow comparison of forests with other protective measures, such as nets and dams. The goal of this study is to quantify the effect of forests on the occurrence frequency and intensity of rockfalls. We therefore defined an onset frequency of blocks based on a powerlaw magnitude-frequency distribution and determined their propagation probabilities on a virtual slope based on rockfall simulations. Simulations were run for different forest and non-forest scenarios under varying forest stand and terrain conditions. We analysed rockfall frequencies and intensities at five different distances from the release area. Based on two multivariate statistical prediction models, we investigated which of the terrain and forest characteristics predominantly drive the role of forest in reducing rockfall occurrence frequency and intensity and whether they are able to predict the effect of forest on rockfall risk. The rockfall occurrence frequency below forested slopes is reduced between approximately 10 and $90 \%$ compared to non-forested slope conditions; whereas rockfall intensity is reduced by 10 to
\end{abstract}

$70 \%$. This reduction increases with increasing slope length and decreases with decreasing tree density, tree diameter and increasing rock volume, as well as in cases of clustered or gappy forest structures. The statistical prediction models reveal that the cumulative basal area of trees, block volume and horizontal forest structure represent key variables for the prediction of the protective effect of forests. In order to validate these results, models have to be tested on real slopes with a wide variation of terrain and forest conditions.

\section{Introduction}

Rockfall is a widespread and frequent natural hazard, occurring below steep rocky cliffs. The occurrence of rockfall often threatens infrastructures, transportation corridors and human life. Here, we define it as a fragment of rock (a block) detaching from a release area and propagating downslope by bouncing, falling or rolling (Whittow, 1984). Different protective measures are typically implemented in order to reduce risks in rockfall-prone areas. These include structural protective measures, land use planning, early warning systems or biological measures, nowadays referred to as nature-based or ecosystem-based solutions (Agliardi and Crosta, 2003; Corominas et al., 2005; Sättele et al., 2016; Renaud et al., 2013). With regard to rockfall, a well-known biological measure is the protection forest. Such forests can serve as a natural means of protection against rockfall due to their barrier 
effect. Forests influence rockfall risk by (i) reducing the intensity of falling rocks after collisions with tree stems and by (ii) reducing the propagation probability and thus the occurrence frequency of an event at a given element at risk (Wasser and Perren, 2014; Dupire et al., 2016). The occurrence frequency is defined here as the product of the onset frequency and the propagation probability of a block at a certain position.

In order to appropriately account for the positive effects of protective measures on rockfall risk and the associated uncertainties, their design should be based on a quantitative risk analysis (Corominas et al., 2005; Straub and Schubert, 2008; Peila and Guardini, 2008). In doing so, the protective effect of the measure can be expressed in monetary terms, thereby allowing its efficiency to be evaluated in a cost-benefit analysis (Agliardi et al., 2009). In the case of protection forests, quantitative, risk-based approaches have been only rarely applied in the past. Despite the advanced knowledge on the protective effect of forests and its maintenance (Dorren et al., 2007; Bigot et al., 2009; Radtke et al., 2014; Fuhr et al., 2015), open questions remain on how protection forests can be quantitatively integrated into rockfall risk analyses (Masuya et al., 2009; Trappmann et al., 2014). Currently, the effect of forests is mostly neglected or only qualitatively assessed in hazard and risk analyses.

The quantification of the influence of forests on rockfall occurrence frequency is particularly demanding, especially if one aims to evaluate the effect of forests at the level of the element at risk. The onset frequency of a rockfall event is usually described by the annual exceedance frequency of its magnitude (expressed as the rockfall volume) or intensity (expressed as the kinetic energy of the blocks), assuming that rockfall occurrence follows a Poisson distribution (Corominas et al., 2013). Depending on the data availability and site characteristics, the onset frequency can be estimated by different approaches including the analysis of historical data sets (Hantz et al., 2003; Hungr et al., 1999; Guzzetti et al., 2003), magnitude-frequency relationships based on power laws (e.g. Agliardi et al., 2009; Lari et al., 2014; DussaugePeisser et al., 2002), empirical models describing rockfall frequency as a function of topographic or geological parameters (e.g. Budetta, 2004; Lan et al., 2010) or expert opinion (e.g. Romana et al., 2003). Furthermore, several techniques exist based on which the depositional ages of rocks can be reconstructed in absolute terms (e.g. Lang et al., 1999; McCarroll et al., 2001). Dendrogeomorphology (Stoffel and Corona, 2014) represents one such approach and has proven to be a reliable method to estimate past rockfall frequencies through coupling the number of rockfall impacts with tree age (Moya et al., 2010; Corona et al., 2013; Trappmann et al., 2014; Perret et al., 2006). However, in most cases, reliable data are scarce and estimation of robust frequencies remains difficult (Hantz et al., 2003; Lari et al., 2014; Straub, 2005). Based on the estimation of the onset frequency, practitioners usually assume scenarios of predefined return periods and corresponding block volumes (e.g. Borter et al., 1999). Such scenarios are typically derived for the current (e.g. forested) situation, but are also applied to hypothetic non-forested situations (Jahn, 1988). At the same time, however, the barrier effect of forests is expected to decrease the occurrence frequency of rockfall at the location of the element at risk. Consequently, scenarios derived with the practitioner's approach may not necessarily be valid for the non-forested situation and might thus result in biased risk estimations.

Forests do not only reduce the occurrence frequency of rockfall events, but also reduce their intensity by stopping blocks completely and/or by absorbing (part of) their energy (Lundström et al., 2009). In this sense, the intensity of an event refers to the kinetic energy which is released by the block at impact with the element at risk (Jaboyedoff et al., 2005; Abbruzzese et al., 2009; Lari et al., 2014).

The effect of forest on the occurrence frequency and the intensity is also expected to depend on the structure of a forest stand. Furthermore, the capacity of a tree to absorb energy will vary between species and will depend on its diameter at breast height (DBH) (Dorren et al., 2006). At the stand level, high stem densities are considered to stop falling blocks more effectively because of an enhanced impact probability (Dorren and Berger, 2005; Wehrli et al., 2006). The three-dimensional, probabilistic-deterministic rockfall simulation model RockyFor3D (Dorren, 2015) accounts for these forest effects. It explicitly integrates trees spatially and calculates the energy loss due to impacts against single trees as a function of tree species, DBH and the height as well as the horizontal position of the impact (Dorren et al., 2006).

The goal of this study is to quantify the effect of forests on the occurrence frequency and intensity of rockfall by using multiple series of rockfall simulations. In this paper, we define a rockfall onset frequency based on a power-law magnitude-frequency distribution. Simulations were run for different forest and non-forest scenarios under varying forest stand and terrain conditions. They provide input data for the determination of rockfall occurrence frequencies and intensities at five different distances from the release area. These data are analysed with multivariate statistical prediction models in order to obtain information on how specific forest and terrain characteristics control rockfall occurrence frequency and intensity along a slope. Based on these approaches, we then investigate (i) how rockfall occurrence frequency and intensity differ at a given location with an element at risk on forested and non-forested slopes, (ii) what terrain and forest characteristics are predominantly driving the role of forest in reducing rockfall occurrence frequency and intensity and (iii) whether multivariate statistical models fitted with these terrain and forest characteristics can indeed predict the effect of forest on rockfall occurrence frequency and intensity and hence rockfall risk. 


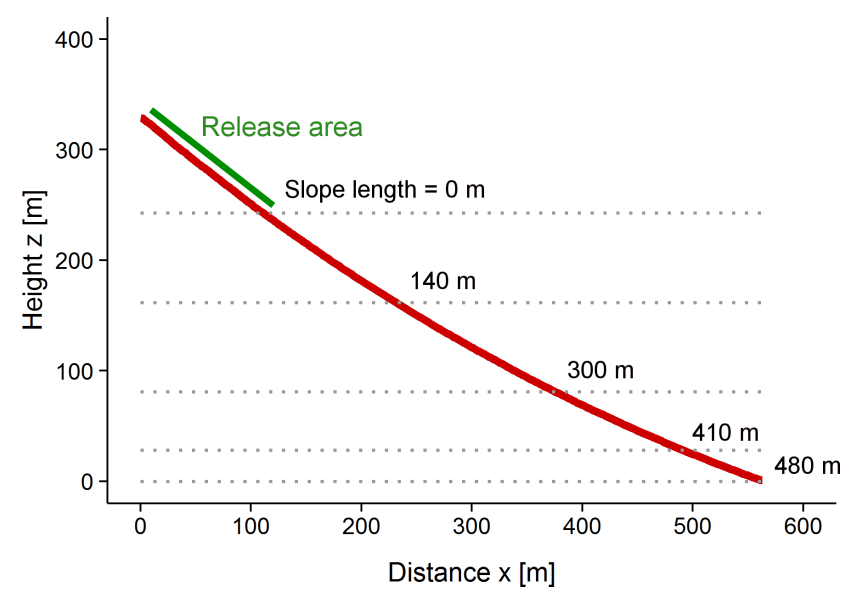

Figure 1. Profile of the virtually constructed digital elevation model (in red) used for the rockfall simulations. Dotted lines with slope lengths measured on the slope indicate the levels at which rockfall occurrence frequency and intensity were evaluated. The rockfall release area is marked in green. The initial fall height of rocks was set to $10 \mathrm{~m}$ above ground.

\section{Material and methods}

\subsection{Virtual slope}

As this study aimed at an assessment of rockfall in forests under controlled conditions, it was preferable to run simulations on a virtual slope. We designed a slope raster with a resolution of $2 \mathrm{~m}$, a horizontal width of $478 \mathrm{~m}$ and a horizontal length of $574 \mathrm{~m}$. The virtual slope is cylindrical, has a concave shape in the vertical cross section, and slope angles which increase linearly from 20 to $40^{\circ}$ from the slope bottom to the release area of rockfalls, therefore resulting in a height difference of $328 \mathrm{~m}$. We chose a concave profile as this corresponds to typical and most frequent slope geometries of rockfall slopes. The rockfall release area is rectangular and has a horizontal length of $100 \mathrm{~m}$ and a width of $300 \mathrm{~m}$ (Fig. 1). Within this area, blocks are released from a height of $10 \mathrm{~m}$ above the slope surface. We added five virtual evaluation lines located at distances of $0,140,300,410$ and $480 \mathrm{~m}$ from the downslope side of the release area to the bottom of the slope (measured on the slope). These lines allow a systematic assessment of changes in rockfall occurrence frequency and intensity with increasing distance from the release area of rockfalls (Fig. 1). The lines were defined based on equal height differences between them.

\subsection{Rockfall simulation model}

To simulate rockfall trajectories, a wide variety of models exist (see Volkwein et al., 2011). For this study, we used the model RockyFor3D, which is a probabilistic process-based rockfall trajectory model simulating trajectories of falling blocks in three dimensions (Dorren, 2015). RockyFor3D was developed on the basis of real-size rockfall experiments in the field and uses raster maps describing topography (digital elevation model, DEM), rockfall source cells, the response of the surface material, slope surface roughness, the number of trees per cell, DBH of trees in each cell and tree species per cell as input data (Dorren et al., 2004, 2006). For each rockfall source cell, the trajectories of a given number of blocks are simulated by considering flying and bouncing. Rolling is simulated with short distance bouncing, similar to the approach of Pfeiffer and Bowen (1989). The trajectory of blocks is primarily determined by topography. The response of the impacted material is considered based on the normal coefficient of restitution $\left(R_{\mathrm{n}}\right)$ which is predefined by seven different soil types or undergrounds. Surface roughness is represented by a mean obstacle height $(\mathrm{MOH})$ representative of 70, 20 and $10 \%$ of each cell (for more details see Dorren, 2015). RockyFor3D explicitly calculates the deviation and energy loss after impacts with trees dependent on tree diameter, impact position and the kinetic energy of the block before the impact. Provided that the exact positions of trees within the slope are not known, trees are randomly positioned within each pixel according to the number of trees (i.e. forest stand density) assigned to each pixel. The main output of RockyFor3D consists of raster cells containing the maximum kinetic energy (the $90 \%$ confidence interval of all maximum kinetic energy values), the maximum bounce height, the number of blocks passed through each cell, the number of deposited blocks, the maximum simulated velocity, the maximum tree impact height and the number of tree impacts per cell (Dorren et al., 2006; Dorren, 2015). We simulated 50 blocks per source cell to obtain robust results and did not consider rock fragmentation.

\subsection{Onset frequency}

We assume a power-law distribution for the magnitudefrequency relationship of blocks released from the release area, since power laws have proven to fit the release volume distribution of rockfalls (e.g. Ruiz-Carulla et al., 2015; Hantz et al., 2016). They have the general form

$F\left(V_{i}\right)=\alpha V_{i}^{-\beta}$,

where $F\left(V_{i}\right)$ is the annual exceedance frequency of volume $i$ $\left(V_{i}\right)$.

We used an exponent $\beta$ of 0.7 which is in the typical range of exponents of power laws fitted for block volume distributions (e.g. Ruiz-Carulla, 2016, 2015; Hantz, 2016). For the scope of our study, we considered blocks with volumes between 0.05 and $2.0 \mathrm{~m}^{3}$. These volumes can be potentially hazardous but are still within a range for which forests are assumed to have an effect on rockfall propagation and energy (Dorren et al., 2007). Moreover, they are highly risk relevant for traffic routes and settlements due to high occurrence frequencies. The constant $\alpha$ of the cumulative power-law distribution was defined as 12 in our study, corresponding to 


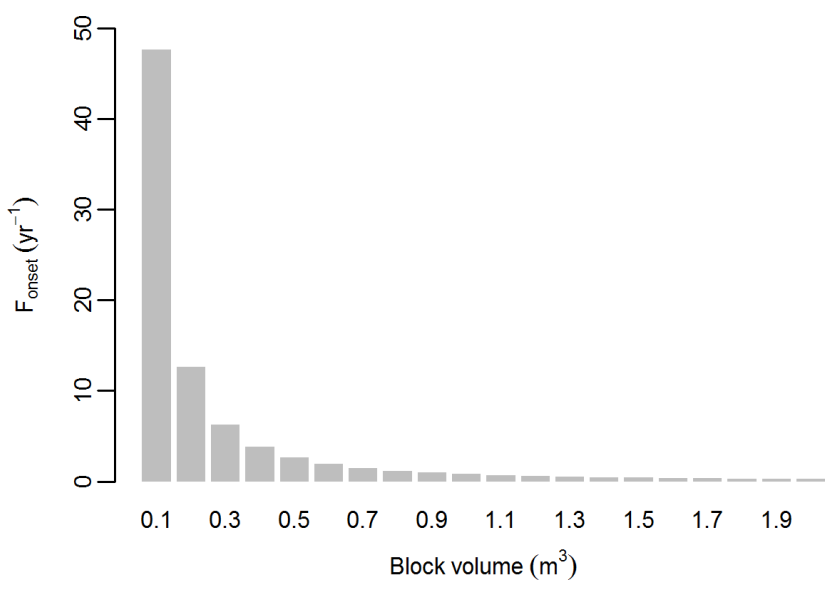

Figure 2. Expected onset frequency (blocks released per year) on the virtual slope. Calculations are based on a power-law volumefrequency relationship, where $\beta$ is the power-law exponent of the cumulative volume frequency distribution and calculated at 0.7 , and where $\alpha$ was set to 12 .

a rockfall retreat rate of approximately $0.2 \mathrm{~mm} \mathrm{yr}^{-1}$ for the considered volume range $\left(0.05\right.$ and $\left.2.0 \mathrm{~m}^{3}\right)$. This is in the typical range of rockfall retreat rates in alpine regions (Sass and Wollny, 2001; Hoffmann and Schrott, 2002; Moore et al., 2009).

\subsection{Forest and terrain scenarios}

The soil scenarios (Table 1) considered scree or medium compact soil with small rock fragments (soil type 3) and talus slope or compact soil with large rock fragments (soil type 4), as these are expected to be most frequent, often continuous and with a large spatial distribution. The release area was in all cases defined as soil type 5 (bedrock with thin weathered material or soil cover). As shown in Table 1, soil roughness was set to $0 \mathrm{~m}(100 \%)$ in the scenario "zero roughness" and to $0.15 \mathrm{~m}$ ( $10 \%$ of the surface), $0.05 \mathrm{~m}$ (20\%) and $0.01 \mathrm{~m}(70 \%)$ in the scenario "rough". Definition of the four forest types (Table 2) was based on natural rockfall protection forests defined by the Swiss National Forest Inventory (Messmer, 2014). The forest types differ with respect to the diameter at breast height (DBH; ranging from 21$40 \mathrm{~cm}$ ), dominant tree species (deciduous, conifers) and the number of tree stems (with $\mathrm{DBH}>12 \mathrm{~cm}$ ) per hectare (Nha; 200-500 trees ha ${ }^{-1}$ ). The forest stands of each forest type were designed for four different horizontal forest structures (Fig. 3) as follows: random tree distribution, clustered tree distribution, random distribution with gaps of $20 \times 20 \mathrm{~m}$ and random distribution with three aisles of $20 \mathrm{~m}$ in width.

The combination of the different forest types (4) and structures (4) and slope scenarios (3) yielded 48 different simulation scenarios.
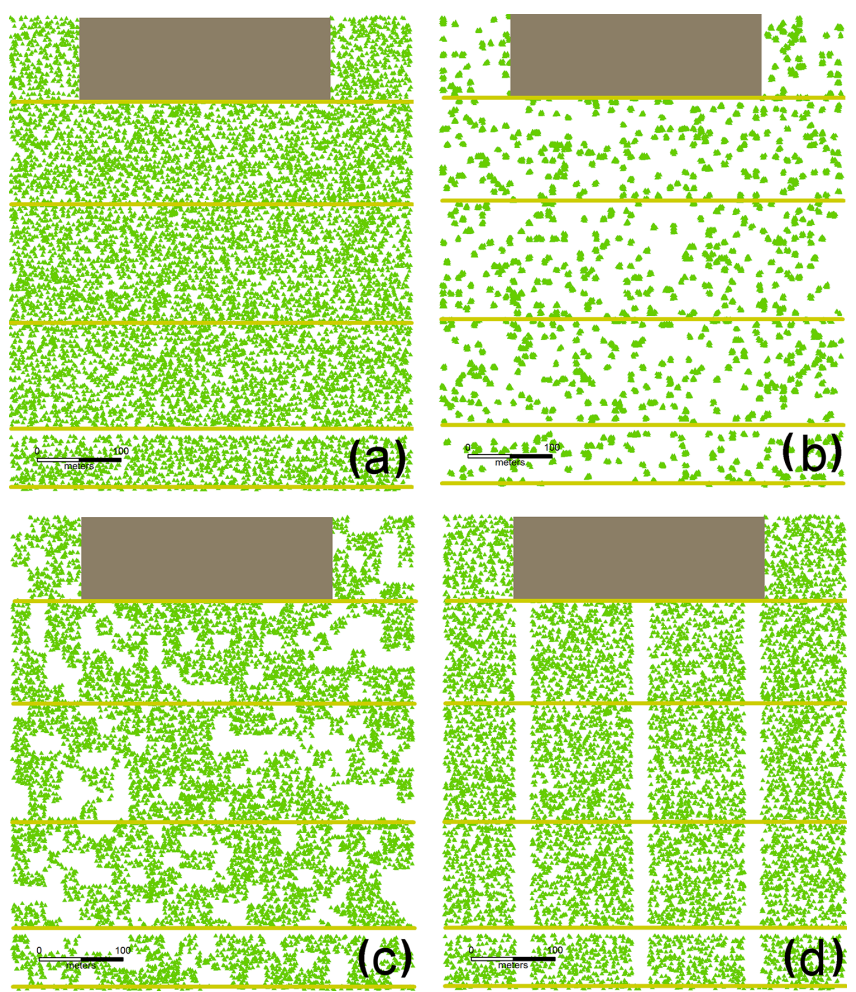

Figure 3. Design of forest structures, release area of rockfalls (grey rectangle) and evaluation lines (EL) for simulation runs. For each forest type, we considered four different scenarios regarding the horizontal forest structure. Forest type 1 is illustrated in (a) with a random tree distribution, (b) with a random distribution of trees in clusters of 10 trees, (c) with a distribution of trees with random gaps (minimum $20 \times 20 \mathrm{~m}$ ) and (d) with three aisles of $20 \mathrm{~m}$ in width starting below the release area of rockfall.

\subsection{Statistical analysis}

Simulation results were analysed statistically as follows:

i. summary of rockfall occurrence frequencies and energies at the level of the evaluation lines,

ii. statistical comparison of rockfall occurrence frequency and intensity between different scenarios and by fitting power-law-based intensity-frequency curves,

iii. design of multivariate statistical models relating the frequency and the intensity reduction of forests to terrain and forest characteristics,

iv. assessment of the performance of the statistical models and sensitivity to changes in slope angle.

For each volume class $j$ and simulation scenario, we calculated the propagation probability $\left(P_{\text {prob,EL }, j}\right.$; Eq. 2$)$ of blocks per evaluation line (EL) by dividing the number of blocks passing an EL (i.e. number of passages, $\mathrm{Nrp}_{\mathrm{EL}}$ ) by the total number of simulated blocks Nrp tot (numbers of source cells $x$ 
Table 1. Soil types and roughness used for the different simulation scenarios according to the classification of Dorren (2015). The release area and the forest road were set to no roughness and soil types 5 and 7, respectively, in all scenarios.

\begin{tabular}{|c|c|c|c|c|}
\hline \multirow[b]{2}{*}{ Soil types } & \multicolumn{3}{|c|}{ Slope scenarios } & \multirow{2}{*}{$\begin{array}{l}\text { Release area } \\
\text { soil type } 5 \text { : bedrock with } \\
\text { thin weathered material or } \\
\text { soil cover }\end{array}$} \\
\hline & $\begin{array}{l}\text { soil type } 3: \text { scree } \\
\varnothing<\sim 10 \mathrm{~cm} \text { or medium } \\
\text { compact soil with small } \\
\text { rock fragments }\end{array}$ & $\begin{array}{l}\text { soil type } 3: \text { scree } \\
\varnothing<\sim 10 \mathrm{~cm} \text { or medium } \\
\text { compact soil with small } \\
\text { rock fragments }\end{array}$ & $\begin{array}{l}\text { soil type } 4: \text { talus slope } \\
\varnothing>\sim 10 \mathrm{~cm} \text { or compact } \\
\text { soil with large rock frag- } \\
\text { ments }\end{array}$ & \\
\hline Roughness & $\begin{array}{l}\text { rough: } 0.15(10 \%), 0.05 \\
(20 \%), 0.01(70 \%)\end{array}$ & no: $0 \mathrm{~m}(100 \%)$ & $\begin{array}{l}\text { rough: } 0.15(10 \%), 0.05 \\
(20 \%), 0.01(70 \%)\end{array}$ & no: $0 \mathrm{~m}(100 \%)$ \\
\hline
\end{tabular}

Table 2. Characteristics of the different forest types used for the rockfall simulations. Values have been taken form the Swiss National Forest Inventory (NFI) data sets published in Messmer (2014).

\begin{tabular}{llrrrr}
\hline $\begin{array}{l}\text { Forest } \\
\text { type }\end{array}$ & Definition & $\begin{array}{r}\text { Mean number of trees ha }{ }^{-1} \\
(\text { with DBH }>12 \mathrm{~cm})\end{array}$ & $\begin{array}{r}\text { Mean DBH [cm] } \\
(\mathrm{DBH}>12 \mathrm{~cm})\end{array}$ & $\begin{array}{r}\text { SD DBH } \\
{[\mathrm{cm}]}\end{array}$ & $\begin{array}{r}\text { Percentage of } \\
\text { conifers [\%] }\end{array}$ \\
\hline 1 & Fagus sylvatica 1 & 460 & 33 & 8.36 & 10 \\
2 & Pinus sylvestris-Larix decidua & 304 & 40 & 10.85 & 100 \\
3 & Fagus sylvatica 2 & 200 & 33 & 8.36 & 10 \\
4 & Pole-stand F. Sylvatica & 500 & 21 & 5.00 & 10 \\
\hline
\end{tabular}

number of simulations per block).

$P_{\text {prob,EL }, j}=\frac{\operatorname{Nrp}_{\mathrm{EL}, j}}{\operatorname{Nrp}_{\text {tot }}}$

Multiplying the propagation probability by the yearly onset frequency $\left(F_{\text {onset }, j}\right)$ of the respective block volume derived from the magnitude-frequency relationship results in the yearly occurrence frequency $\left(F_{\text {occ,EL }, j}\right.$; Eq. 3 ) per EL and block volume $j$.

$F_{\text {occ }, \mathrm{EL}, j}=P_{\text {prob }, \mathrm{EL}, j} \times F_{\mathrm{occ}, j}$

We calculated an indicator for the reduction in the number of passages by the forest stand $\left(\mathrm{Nrp}_{\mathrm{red}}\right)$ in order to evaluate changes in the frequency between forested and non-forested

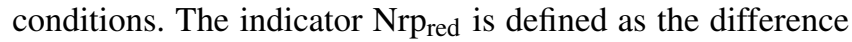
between the number of passages without $\left(\mathrm{Nrp}_{\mathrm{nF}}\right)$ and with forest $\left(\mathrm{Nrp}_{\mathrm{F}}\right)$, divided by the number of passages without forest (Eq. 4):

$\mathrm{Nrp}_{\text {red }}=\frac{\operatorname{Nrp}_{n F}-\operatorname{Nrp}_{F}}{\operatorname{Nrp}_{n F}}$.

We then used the 90th percentile of the maximum energy $(\mathrm{E} 90 \mathrm{in} \mathrm{kJ})$ as an indicator for rockfall intensity. For each EL, we calculated the E90 of all blocks passing the line. Similarly to occurrence frequency, we calculated the intensity reduction offered by forests (E90 red $)$. This indicator is defined as the difference between E90 without $\left(\mathrm{E} 90_{\mathrm{nF}}\right)$ and with forest $\left(\right.$ E90 ${ }_{\mathrm{F}}$ ) divided by $\mathrm{E} 90_{\mathrm{nF}}$ (Eq. 5):

$\mathrm{E} 90_{\mathrm{red}}=\frac{\mathrm{E} 90_{\mathrm{nF}}-\mathrm{E} 90_{\mathrm{F}}}{\mathrm{E} 90_{\mathrm{nF}}}$.
We further determined intensity-frequency distributions of E90 (intensity) and $F_{\text {occ }}$ (occurrence frequency) under different forest and non-forest scenarios and at a slope length of $300 \mathrm{~m}$, to which power-law distributions (Eq. 1) were fitted based on least squares (Draper and Smith, 1998).

To detect possible effects of forest and terrain characteristics on the forest effect, we first assessed whether Nrp red $_{\text {and }}$ E90 red significantly differ between different forest and terrain scenarios based on the Wilcoxon rank-sum test, with a significance threshold of $p \leq 0.05$. Subsequently, we applied regression tree (RT) models (Breiman et al., 1984) and generalized linear models (GLMs) (McCullagh and Nelder, 1989) relating $\mathrm{Nrp}_{\text {red }}$ and $\mathrm{E} 90_{\text {red }}$ to possible explanatory variables.

RTs are a non-parametric regression approach which recursively partition the data based on explanatory variables. At each node, the data are split into two groups using a single predictor (Breiman et al., 1984). The splitting variable is selected to aim for impurity reduction. This means that daughter nodes have to be as homogeneous (pure) as possible. RTs consider parameter interactions and account for non-linearities (Vorpahl et al., 2012). RT models were fitted using the rpart function of the party package in the statistical software R (Ripley et al., 2015).

We used rock volume, soil type (categorical), soil roughness (categorical), the horizontal forest structure (categorical) and the cumulative basal area (cbA; Eq. 6) of the forest as potential explanatory variables. The latter is defined as the product of the relative basal area $\left(\mathrm{rbA} ; \mathrm{m}^{2} \mathrm{ha}^{-1}\right)$ for a slope width of $100 \mathrm{~m}$ and the forested slope length (fsL; m) from the top of the release area to the respective EL. The relative basal area (rbA) is defined as the area per hectare which is 
occupied by the cross section of tree stems (Bitterlich, 1948).

$\operatorname{cbA}\left[\mathrm{m}^{2} \mathrm{ha}^{-1}\right]=\frac{\mathrm{rbA}}{100 \mathrm{~m}} \times \mathrm{fsL}=\frac{\sum_{\mathrm{EL}} \mathrm{bA} / \sum_{\mathrm{EL}} \text { area }}{100 \mathrm{~m}} \times \mathrm{fsL}$

We calculated the Spearman correlation coefficients to check that the explanatory variables are not substantially correlated (Spearman <4; Dancey and Reidy, 2011). The final GLM was determined using a stepwise backward variable selection with the aim to minimize the Akaike Information Criterion (AIC). The quality of the models was examined with goodness-of-fit tests and customary residual diagnostic plots (Stahel, 2013), indicating that the cbA should be transformed to the natural logarithm.

The GLM and RT were fitted with the simulation data of the concave slope. They were calibrated with a training data set representing $75 \%$ of the data. We further applied a 10 -fold cross validation that was repeated three times and calculated the average performance across the hold-out predictions with the aim of avoiding overfitting (Kohavi, 1995). The predictive performance was assessed based on the root mean square error normalized with the range of the simulated data (nRMSE).

Furthermore, we tested the statistical prediction models for $\mathrm{Nrp}_{\text {red }}$ with field data of a study site in the French Alps at which real-size rockfall experiments were conducted on forested and non-forested sites (Dorren et al., 2006). We evaluated $\mathrm{Nrp}_{\text {red }}$ at a distance of 223 and $324 \mathrm{~m}$ from the release point (as measured along the slope).

To assess whether the forest effect on rockfall occurrence frequency and intensity depends on the slope angle, we conducted additional simulations for four linear-shaped slopes with varying slope angles $\left(32,35,38\right.$ and $\left.40^{\circ}\right)$ for forest type 1 with random tree distribution, soil type 3 and rough conditions. On these slopes, we tested the multivariate statistical prediction models designed for the concave slope (GLM, RT) and calculated their performance. On the linear-shaped slopes, evaluation lines were defined with the same distances along the slopes.

\section{Results}

\subsection{Effect of forest on rockfall occurrence frequency}

Forest stands considerably reduce rockfall occurrence frequency, with differences in frequency between the forested and non-forested slope scenarios increasing strongly with increasing slope length. In the case of forest type 1 ( $F a$ gus sylvatica forest with 460 stems ha $^{-1}$ ) with randomly distributed trees, the frequency at a distance of $480 \mathrm{~m}$ from the release area has been shown to decrease to zero whereas on the non-forested slope, $F_{\text {occ }}$ remains at values ranging from 0.1 to $1 \mathrm{yr}^{-1}$, depending on block volume (Fig. 4). We also show that with decreasing cbA, the effect of the forest is

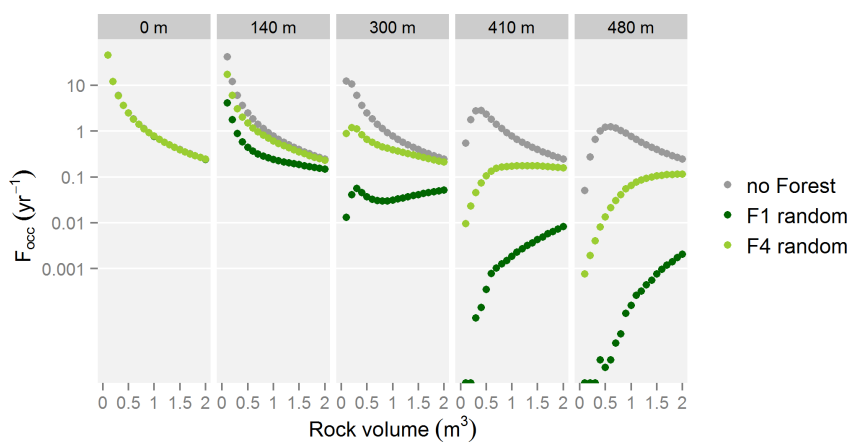

Figure 4. Occurrence frequencies of rockfalls (onset frequency $\times$ propagation probability) at different evaluation lines located at $0-480 \mathrm{~m}$ downslope of the release area and for block volumes ranging from 0.05 to $2.0 \mathrm{~m}^{3}$ under forested (forest type 1 (F1): dark green; forest type 4 (F4): light green) and non-forested conditions (grey) with a random tree distribution, soil type 3 and rough slope conditions. Note that the $y$ axis is log-transformed. 50 simulations were run per block.

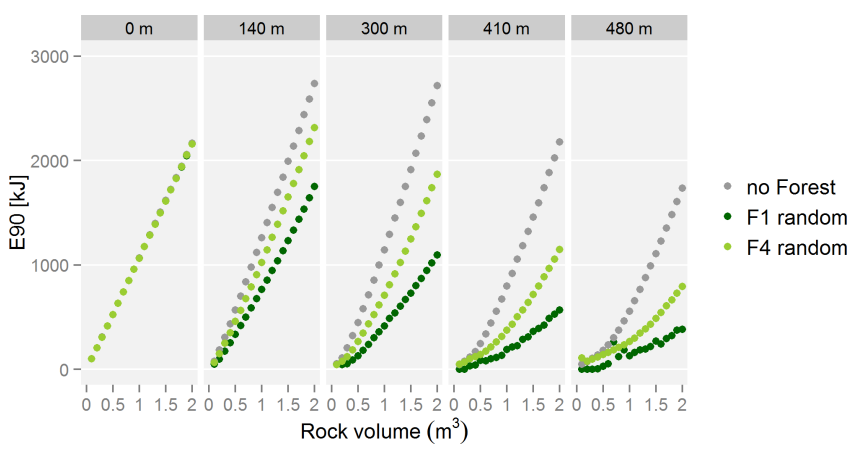

Figure 5. Illustration of the 90th percentile of maximum kinetic energies (E90) of blocks at different evaluation lines located at 0 $480 \mathrm{~m}$ downslope of the release area based on 50 simulations per block. As before, results include a range of rock volumes from 0.05 to $2.0 \mathrm{~m}^{3}$ under forested (forest type 1 (F1): dark green; forest type 4 (F4): light green) and non-forested conditions (grey) and with a random tree distribution, soil type 3 and rough slope conditions.

decreasing ( $p<0.05$; Fig. 6$)$, and the reduction of rockfall is becoming less effective. By contrast, in a pole-stand $F$. sylvatica forest (forest type 4) $F_{\text {occ }}$ decreases to values between 0.001 and $0.01 \mathrm{yr}^{-1}$ at a slope length of $450 \mathrm{~m}$. In the conifer forest composed of Pinus sylvestris and Larix decidua (forest type 2 ), $F_{\text {occ }}$ is slightly higher compared to deciduous forests. Furthermore, we also illustrate that differences between forested and non-forested slopes will chiefly depend on forest structure. In this sense, $\mathrm{Nrp}_{\text {red }}$ is significantly smaller for a clustered tree distribution, gaps or aisles than for a random tree distribution $(p<0.05)$.

The protection effect of the forest decreases with increasing block volume (Fig. 7; $p<0.05$ ). This is especially pronounced for forests with small tree diameters (e.g. forest 


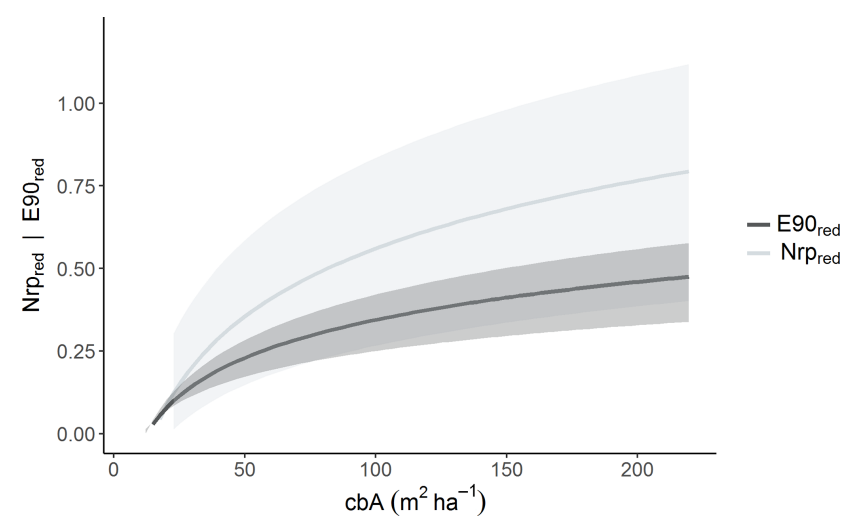

Figure 6. Nrp red (light grey) and $\mathrm{E} 90_{\text {red }}$ (dark grey) based on the simulation of all forest and terrain scenarios on the concave slope and depending on cbA using a logarithmic smoothing function and the respective 10 and $90 \%$ quantiles (shaded).

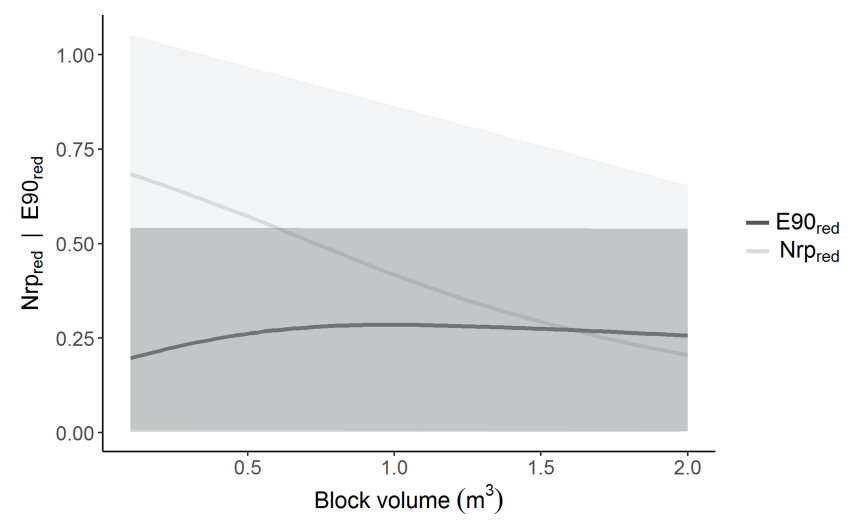

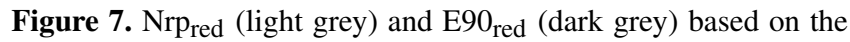
simulation of all forest and terrain scenarios on a concave slope and depending on rock volume using a loess smoothing function and the respective 10 and $90 \%$ quantiles (shaded).

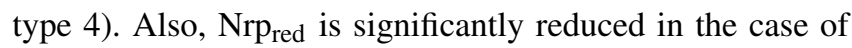
zero roughness $(p<0.05)$. A significant difference in $\mathrm{Nrp}_{\text {red }}$ also exists between soil types 3 and 4 (see Table 1).

According to the final generalized linear model $\left(\mathrm{GLM}_{\text {Freq }}\right)$, Nrp red $_{\text {red }}$ is significantly influenced by the cbA, block volume, horizontal forest structure, soil type, soil roughness and the percentage of conifers present in the forest stand (Table 3). GLM $M_{\text {Freq }}$ has a $R^{2}$ of 0.80 and a nRMSE of 0.16 with cross-validation for the training data set and the test data set. We also realize that the nRMSE changes only slightly if GLM Freq $_{\text {is applied to linear slopes }}$ (Table 4).

The variables reported above were also decisive in the regression tree model $\left(\mathrm{RT}_{\text {Freq }}\right.$; Fig. 8). The data set was first partitioned based on a threshold of $\sim 75 \mathrm{~m}^{2} \mathrm{ha}^{-1}$ for $\mathrm{cbA}$. In the case where cbA is larger than this value, Nrpred is between 0.3 and 1. At the same time, however, Nrp red clearly decreases in the case that block volumes become $>\sim 1 \mathrm{~m}^{3}$. On the other hand, and if cbA is smaller than

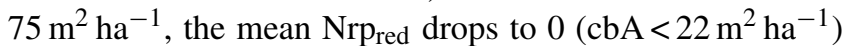
and $0.4\left(\mathrm{cbA}>22 \mathrm{~m}^{2} \mathrm{ha}^{-1}\right.$ and a block volume $\left.<0.6 \mathrm{~m}^{3}\right)$. The nRMSE of $\mathrm{RT}_{\text {Freq }}$ is 0.16 with cross-validation for the training data set and 0.17 for the test data set. As can be seen from Table 4, the nRMSE is in the same range of values for the linear slopes.

In the case of the field site in Vaujany (Table 5), for which real data exist from experiments, the GLM Freq and the $\mathrm{RT}_{\text {Freq }}$ models predict $\mathrm{Nrp}_{\text {red }}$ values of 0.55 and 0.61 , respectively, at a distance of $223 \mathrm{~m} \mathrm{(0.64} \mathrm{is} \mathrm{the} \mathrm{observed} \mathrm{value} \mathrm{during} \mathrm{the}$ experiments) and 0.66 and 0.73 , respectively, at a distance of $324 \mathrm{~m}$ (1.0 is the observed value during the experiments).

\subsection{Effect of forest on rockfall intensity}

On the concave slope, the blocks reach energies of up to $2700 \mathrm{~kJ}$ under non-forested conditions and $2000 \mathrm{~kJ}$ under forested conditions at a slope length of $300 \mathrm{~m}$. Similarly to the rockfall occurrence frequency, energy is distinctly reduced on the forested slopes compared to the non-forested slope (Fig. 5). Again, the reduction by the forest is decreased with decreasing $\mathrm{cbA}$, increasing block volume and for the clustered and gappy forest structures (Figs. 6-8). Furthermore, E90 red is significantly smaller on slopes with soil type 4 compared to slopes with soil type $3(p<0.05)$, but is not significantly reduced on slopes with zero roughness.

In the final GLM $\left(G M_{I n t}\right)$, the horizontal forest structure, percentage of conifer trees, cbA, soil roughness, soil type and block volume have a significant effect on E90 ${ }_{\text {red }}$. GLM Int has a $R^{2}$ of 0.69 and a nRMSE of 0.05 with cross-validation for the training data set and 0.08 for the test data set. If GLM $_{\text {Int }}$ is applied to linear slopes, we observe that the nRMSE values increase only slightly (Table 4).

In the regression tree model ( $\left.\mathrm{RT}_{\text {Int }}\right), \mathrm{cbA}$ and horizontal forest structure were selected as splitting variables. Figure 7 illustrates that in the case of high $\mathrm{cbA}\left(>85 \mathrm{~m}^{2} \mathrm{ha}^{-1}\right), \mathrm{E} 90_{\text {red }}$ is distinctively smaller with a clustered or gappy forest structure. We also observe a couple of outliers with E90 ${ }_{\text {red }}$ values around -1.5 for high cbA values (see Fig. 8). These cases represent blocks passing the lowest evaluation line at $480 \mathrm{~m}$ under forested conditions, which have relatively high energies compared to non-forested conditions $\left(\mathrm{E} 90_{\mathrm{F}}=118.1 \mathrm{~kJ}\right.$; $\mathrm{E} 90_{\mathrm{nF}}=47.1 \mathrm{~kJ}$ ). Only these few high-energy blocks (e.g. $\mathrm{Nrp}_{\mathrm{F}}=3 ; \mathrm{Nrp}_{\mathrm{nF}}=398$ for $0.1 \mathrm{~m}^{3}$ ) are able to reach such runout distances under forested conditions and strongly determine the statistics. The $\mathrm{nRMSE}_{\text {of }} \mathrm{RT}_{\text {Int }}$ is 0.04 with crossvalidation for the training data set and 0.08 for the test data set. Similarly to $\operatorname{GLM}_{\text {Int }}$, we observe that the nRMSE of $\mathrm{RT}_{\text {Int }}$ values hardly changes on linear slopes (Table 4). 

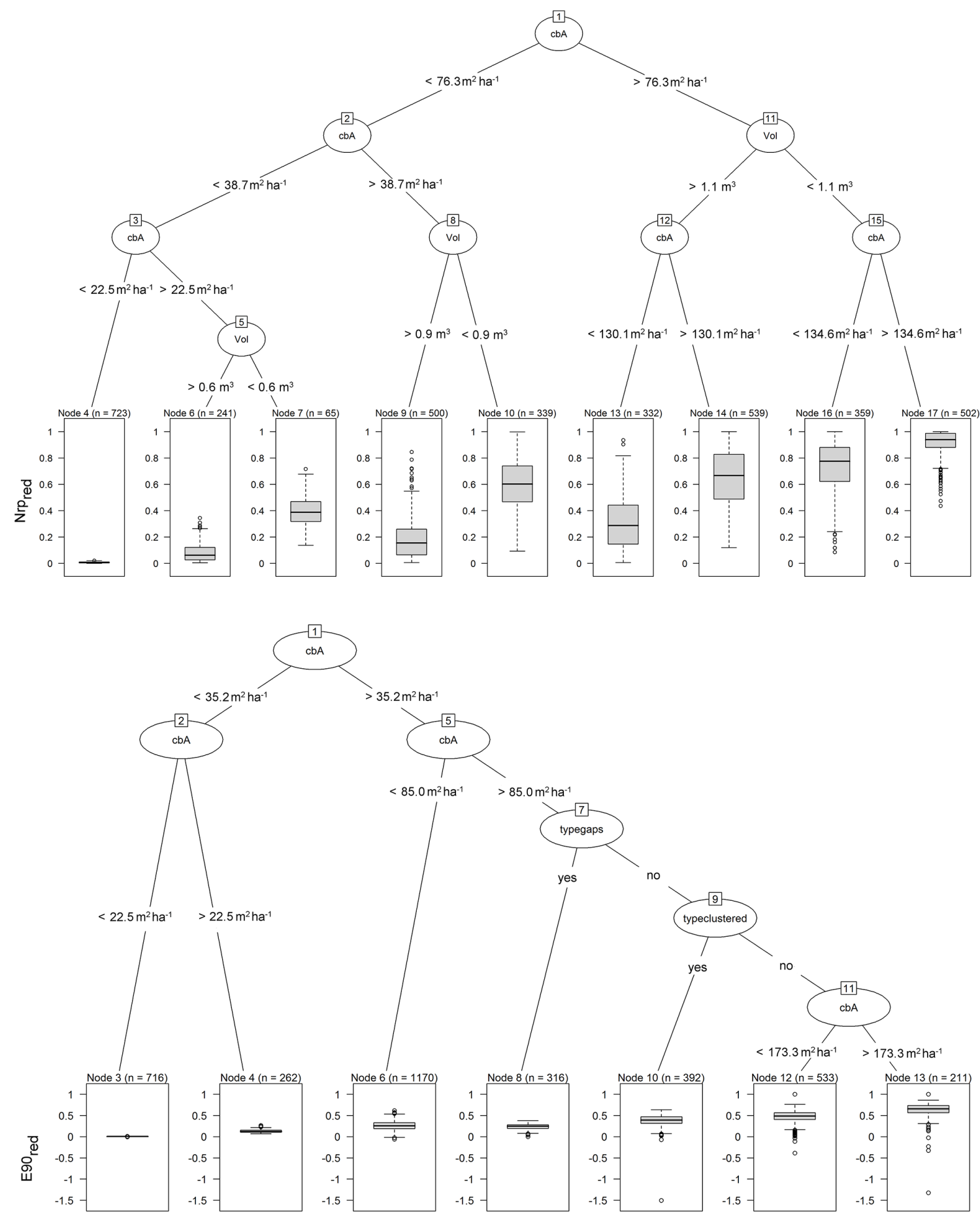

Figure 8. Regression tree models were used to predict the reduction in rockfall occurrence frequency $\left(\mathrm{RT}_{\text {Freq }}\right.$; above) and the reduction in rockfall intensity $\left(\mathrm{RT}_{\text {Int }}\right.$; below) by forests. The models were fitted with a training set representing $75 \%$ of the entire data set $(n=3600)$ and by applying a 10-fold cross-validation three times. The nodes represent the splitting variables followed by the applied threshold value. $\mathrm{cbA}$ is cumulative basal area $\left[\mathrm{m}^{2} \mathrm{ha}^{-1}\right]$, Vol is volume $\left[\mathrm{m}^{3}\right]$, typegaps is gappy tree distribution [yes, no], typeclustered is a clustered tree distribution [yes, no]. 
Table 3. Estimated regression coefficients, standard errors, $Z$ values (i.e. ratio of estimate and standard error) and $p$ values of the parametric explanatory variables and the intercept of the general linear model (GLM) for the reduction in rockfall occurrence frequency by forests $\left(\mathrm{GLM}_{\text {Freq }}\right)$ and the GLM for the reduction in rockfall intensity $\left(\mathrm{GLM}_{\mathrm{Int}}\right)$ by forests. The models were fitted with a training set representing $75 \%$ of the entire data set $(n=3600)$ applying a 10 -fold cross-validation three times. Note that $R^{2} \mathrm{GLM}_{\text {Freq }}=0.80$ and $R^{2} \mathrm{GLM}_{\text {Int }}=0.69$.

\begin{tabular}{lrr|rr|rr|rr}
\hline & \multicolumn{2}{c}{ Estimate } & \multicolumn{2}{c|}{ SE } & \multicolumn{2}{c|}{$Z$ value } & \multicolumn{2}{c}{$p(>|z|)$} \\
\cline { 2 - 8 } & GLM $_{\text {Freq }}$ & \multicolumn{1}{c|}{ GLM $_{\text {Int }}$} & GLM $_{\text {Freq }}$ & GLM $_{\text {Int }}$ & GLM $_{\text {Freq }}$ & GLM $_{\text {Int }}$ & GLM $_{\text {Freq }}$ & GLM $_{\text {Int }}$ \\
\hline Intercept & -0.46 & -0.38 & 0.014 & 0.01 & -32.54 & -35.99 & $<2 \times 10-16$ & $<2 \times 10-16$ \\
Vol & -0.26 & 0.02 & 0.005 & 0.003 & -55.91 & 6.52 & $<2 \times 10-16$ & $7.85 \times 10-11$ \\
$\log (\mathrm{cbA})$ & 0.30 & 0.17 & 0.003 & 0.002 & 100.56 & 80.40 & $<2 \times 10-16$ & $<2 \times 10-16$ \\
type clustered & -0.09 & -0.0 .13 & 0.007 & 0.007 & -13.60 & -24.55 & $<2 \times 10-16$ & $<2 \times 10-16$ \\
type gaps & -0.04 & -0.18 & 0.007 & 0.007 & -6.06 & -31.14 & $1.51 \times 10-09$ & $<2 \times 10-16$ \\
soil type 4 & -0.02 & 0.01 & 0.006 & 0.004 & -2.95 & 3.00 & 0.003 & 0.009 \\
Roughness 2 & -0.07 & 0.03 & 0.006 & 0.004 & -12.09 & 7.89 & $<2 \times 10-16$ & $3.92 \times 10-15$ \\
Conifer percent 100 & -0.03 & -0.06 & 0.007 & 0.005 & -4.76 & -11.72 & $<2 \times 10-16$ & $<2 \times 10-16$ \\
\hline
\end{tabular}

Table 4. Normalized root mean square error (nRMSE) of the generalized linear models (GLM) and the regression tree models (RT) predicting $\mathrm{Nrp}_{\text {red }}\left(\mathrm{GLM}_{\text {Freq }}, \mathrm{RT}_{\text {Freq }}\right)$ and $\mathrm{E} 0_{\text {red }}\left(\mathrm{GLM}_{\text {Int }}, \mathrm{RT}_{\text {Int }}\right)$ with a 10-fold cross-validation (cv) three times and for predictions of the test data set ( $25 \%$ of the data) and linear slopes with varying slope angle (slopes $2-5$ ).

\begin{tabular}{lrrrrrr}
\hline Model & nRMSE cv & nRMSE test & nRMSE slope 2 & nRMSE slope 3 & nRMSE slope 4 \\
& & & $\left(32^{\circ}\right)$ & $\begin{array}{r}\text { nRMSE slope 5 } \\
\left(45^{\circ}\right)\end{array}$ \\
\hline GLM $_{\text {Freq }}$ & $16 \%$ & $16 \%$ & $20 \%$ & $17 \%$ & $12 \%$ & $11 \%$ \\
RT Freq $_{\text {FLM }}$ & $16 \%$ & $17 \%$ & $21 \%$ & $17 \%$ & $11 \%$ & $10 \%$ \\
RT $_{\text {Int }}$ & $5 \%$ & $8 \%$ & $17 \%$ & $15 \%$ & $14 \%$ & $13 \%$ \\
\hline
\end{tabular}

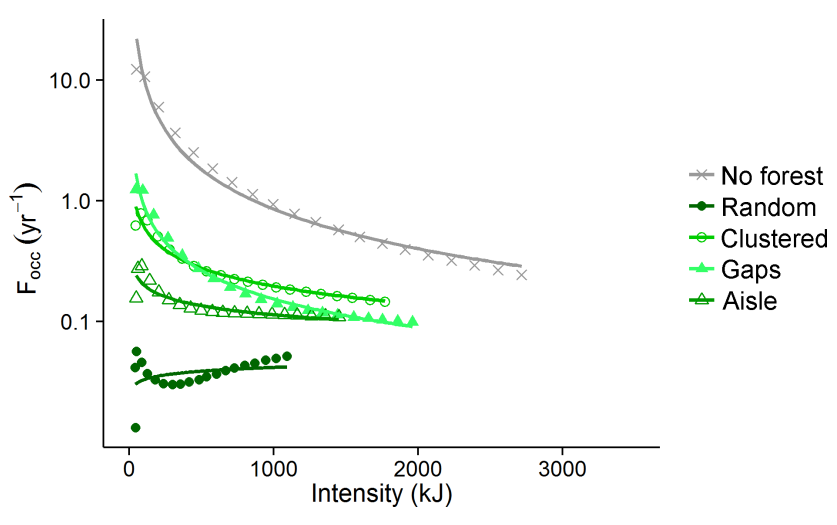

Figure 9. Frequency-intensity distributions with fitted power laws at a distance of $300 \mathrm{~m}$ from the release area for forest type 1 (Table 2) with different horizontal forest structures and without forest. The intensity is expressed as the 90th percentile of the maximum kinetic energy of the simulated blocks (50 blocks per source cell) passing through the evaluation line.

\subsection{Intensity-frequency curves}

Analysis of intensity-frequency distributions of rockfalls depends strongly on the forest cover. In the case of nonforested slopes, the intensity-frequency curve is substantially shifted upward compared to forested slopes at a dis- tance of $300 \mathrm{~m}$ downslope from the start area, thereby indicating a higher frequency (intensity) for a given intensity (frequency) (Fig. 9). In other words, the $\beta$ and the $\alpha$ coefficients (Eq. 1) of the power law fitted to the intensityfrequency distributions are considerably lower when forest cover is present compared to non-forested conditions (Table 6). Furthermore, the occurrence frequencies of small intensities are distinctly reduced on forested slopes (rollover effect).

\section{Discussion and conclusion}

In this study we investigated the role of forests - in terms of stand density and species composition - on rockfall occurrence at increasing distances from the release area of rockfalls by using a hypothetical slope typical of mountain environments. Based on a large number of simulation runs using different scenarios, we show that rockfall occurrence frequency below forested slopes is reduced between approximately 10 and $90 \%$ compared to non-forested slope conditions. Rockfall intensity is also reduced, although to a slightly smaller extent, by 10 and $70 \%$. These findings are in agreement with the study of Lopez-Saez et al. (2016) who found a distinct increase in rockfall return periods (e.g. from 143 years in 1850 to $>2000$ years in 2013 under a distinct 
Table 5. Model input parameters and predicted values of Nrp red with the GLM and the RT model as well as the measured value for Nrp red for the study site in Vaujany where (Dorren et al., 2006) performed real-size rockfall experiments.

\begin{tabular}{lrrlrlrrr}
\hline Position & $\begin{array}{r}\text { Vol } \\
{\left[\mathrm{m}^{3}\right]}\end{array}$ & $\begin{array}{r}\text { cbA } \\
{\left[\mathrm{m}^{2} \mathrm{ha}^{-1}\right]}\end{array}$ & $\begin{array}{l}\text { Forest } \\
\text { type }\end{array}$ & $\begin{array}{r}\text { Soil } \\
\text { type }\end{array}$ & Roughness & $\begin{array}{r}\text { Nrpred } \\
\text { (true) }\end{array}$ & $\begin{array}{r}\text { Nrpred } \\
\text { (pred, GLM) }\end{array}$ & $\begin{array}{r}\text { Nrpred } \\
\text { (pred, RT) }\end{array}$ \\
\hline Middle slope & 0.5 & 70.5 & random & 4 & rough & 0.64 & 0.55 & 0.61 \\
Bottom slope & 0.5 & 102.4 & random & 4 & rough & 1.0 & 0.66 & 0.73 \\
\hline
\end{tabular}

Table 6. $\alpha$ and $\beta$ coefficient and adjusted $R^{2}$ with least-squares fitted power laws of the non-cumulative frequency-intensity distributions at a distance of $300 \mathrm{~m}$ from the release area for forest type 1 with different horizontal forest structures and without forest.

\begin{tabular}{lrrc}
\hline Forest structure & $\alpha$ & $\beta$ & $R^{2}$ \\
\hline No forest & 7.38 & 1.09 & 0.98 \\
Random & -3.69 & -0.10 & 0.08 \\
Clustered & 1.81 & 0.5 & 0.95 \\
Aisle & -0.45 & 0.25 & 0.75 \\
Gaps & 3.54 & 0.78 & 0.98 \\
\hline
\end{tabular}

increase in forest cover and for a block volume of $\left.1.2 \mathrm{~m}^{3}\right)$. In this particular case in the Chartreuse massif (France), the disappearance of viticultural landscapes has led to intense (natural) afforestation and can thus be seen as a natural example for the validation of our theoretical results. Similarly to our study, Lopez-Saez et al. (2016) also observed that the kinetic energy of rocks clearly decreases at the bottom of the slope and with increasing forested surface, which is again in concert with the findings of our study. Stoffel et al. (2005) investigated spatial and temporal variations of rockfall activity in a protection forest in the Swiss Alps based on dendrogeomorphic data. They reconstructed a decrease in rockfall rates after the recolonization of part of the slope where most of the forest was destroyed after a high-magnitude event in 1720. Masuya et al. (2009), on the other hand, did not find a decrease in the number of blocks reaching the damage potential at a distance of $350 \mathrm{~m}$ from the rockfall source based on three-dimensional simulations taking vegetation probabilistically into account, but an increase in the spread of the rockfalls and lower rock energies. It has to be mentioned that the considered vegetation cover featured relatively small trees and low tree density.

The multivariate statistical models used in this study allowed quantification of the reduction of rockfall occurrence frequency and intensity and its prediction under varying forest and slope conditions. Both models (GLM and RT model) revealed that the effect a forest stand has on rockfall will depend clearly on the cumulative basal area (cbA) of trees, the horizontal forest structure and on the block volume. We realize that the occurrence frequency and intensity are significantly increased with decreasing cbA and increasing block volume as well as in clustered or gappy forests, and are now able to quantify these effects. Moreover, the results also demonstrate how the protective effect of forests is enhanced with increasing soil roughness and capacity of the soil to dissipate energy. The influence of the two slope parameters was, however, significant in the GLM, but not in the RT model.

According to the RT models, the forest effect of rockfall frequency appears to depend mainly on cbA and rock volume, whereas cbA and forest structure appear to be the most decisive factors for the reduction in rockfall intensity. Block volume, by contrast, only has a small influence on the effect of forest on rockfall intensity (Fig. 7). The maximum reduction of the rockfall energy by forests is reached for volumes between approximately 0.6 and $1.0 \mathrm{~m}^{3}$. This appears to be the optimal combination between a sufficiently high tree impact probability and impact energy. For larger blocks, however, impact probability increases further, but the block energy cannot be dissipated during a single tree impact.

The cbA appears to be a good measure of the protective efficacy of forests, as it combines the basal area (which is determined by tree density and tree diameter) with the forested slope length - two parameters which have been promoted as key variables for forest management in previous work (Perret et al., 2004; Berger and Dorren, 2007; Rammer et al., 2015; Fuhr et al., 2015). In a recent study, Dupire et al. (2016) showed that the protective effect of forests regarding rockfall frequency and energy can be evaluated only on their basal area, their mean diameter at breast height and the length of the forested slope. Based on our results, we recommend a minimum cbA of about $80 \mathrm{~m}^{2} \mathrm{ha}^{-1}$ for block volumes larger than $1 \mathrm{~m}^{3}$ and a minimum cbA of about $30-40 \mathrm{~m}^{2} \mathrm{ha}^{-1}$ for volumes smaller than $1 \mathrm{~m}^{3}$. Compared to the minimum threshold of $20 \mathrm{~m}^{2} \mathrm{ha}^{-1}$ for the basal area of a rockfall protection forest as suggested by Dorren et al. (2015), this corresponds to forested slope lengths of $450 \mathrm{~m}$ (block volume $>1 \mathrm{~m}^{3}$ ) and $200 \mathrm{~m}$ (block volume $<1 \mathrm{~m}^{3}$ ), respectively.

According to the RT models, the horizontal forest structure is particularly important when it comes to the reduction of rockfall intensity. We demonstrate that the kinetic energies of blocks are significantly higher in the case of forest stands with a clustered tree structure or in forests with gaps or aisles compared to random tree distribution. The horizontal forest structure, by contrast, is only of secondary importance for the reduction of rockfall frequency, and the number of trees which are impacted by the block in motion will be decisive. 
Radtke et al. (2014) found significantly longer run distances in forests with clustered tree distribution compared to random distribution based on rockfall simulations.

The performance of the implemented statistical prediction models is satisfactory. They yielded relatively low nRMSE, also when applying cross-validation. This indicates that the generalization capacity of the models is relatively high and overfitting unlikely. The application of the models to four different linear slopes with varying slope angles $(32,35,38$ and $40^{\circ}$ ) only slightly increased the nRMSE (Table 4) suggesting that the models are relatively robust with respect to slope angles.

Various factors influence the robustness of the developed models with respect to their applicability to real slopes. The simulated block volume was limited to $2.0 \mathrm{~m}^{3}$ and therefore they do not necessarily apply to larger volumes. In the

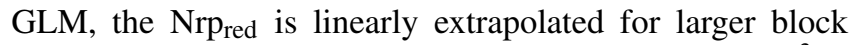
volumes, whereas in the RT model a threshold of $2.0 \mathrm{~m}^{3}$ is fixed and the reductive effect of the forest for larger volumes might be overestimated. Furthermore, since we used the rockfall model Rockyfor3D as an important basis for this study, we assume that this model simulates the rockfall process and impacts against trees are sufficiently realistic. It has to be considered, however, that the model takes into account two "species" only, coniferous and broadleaved, for calculating the energy dissipative capacity of trees. In reality, the range of this capacity is much larger and shows huge variations, for example, due to tree vitality, tree anchoring and other site conditions determining tree growth. Additionally, Rockyfor3D uses a simplified stochastic approach to account for different block shapes. When considering a single block event with a rock shape that does not correspond to standard shapes such as rectangular or spherical, differences between the model and reality can be expected.

We could show that the intensity-frequency distributions of rockfall events can be significantly altered below forests compared to non-forested situations. On forested slopes, we observed a typical rollover effect for small intensities (e.g. Malamud et al., 2004). This supports the importance of a coupled consideration of intensity and frequency in order to fully account for the forest effect as it was already reported for other natural hazard processes (Alila et al., 2009). Otherwise, risk analyses are expected to be biased and the risk below forests may be overestimated, resulting in overdimensioned structural protection measures associated with high costs.

Overall, this study substantiates the importance of forests in reducing rockfall risk. The statistical prediction models based on the simulation results for different forest and terrain scenarios allow this effect to be quantified and predicted for other slopes, given the constraints mentioned above. In order to validate these results, the models have to be tested on real slopes. Dendrogeomorphic data on tree impacts (Trappmann and Stoffel, 2013, 2015; Morel et al., 2015) might help to evaluate changes in frequency reduction along the slope depending on the forest structure (Corominas and Moya, 2010). However, serious validation of the difference between forested and non-forested slopes remains difficult since data is missing.

The shown influence of the forest type and structure on rockfall occurrence frequency and intensity underlines the importance of forest management aiming at maintaining its protection function. Disturbances, such as fire, wind or insects, can temporarily eliminate or at least substantially reduce the protective effect of forests (Maringer et al., 2016; Cordonnier et al., 2008). Also the rockfall process itself, particularly extreme rockfall events, can destroy considerable parts of the forest, thus encompassing higher rockfall frequency and intensity in the following years (Stoffel et al., 2005).

Data availability. The simulation-based input data of the statistical analysis can be accessed on request from the author. The simulations are based on the three-dimensional rockfall model RockyFor3D, accessible on www.ecorisq.org.

Competing interests. The authors declare that they have no conflict of interest.

Acknowledgements. This study was financially supported by the SNF-ANR project "ALIEN - Assessing long term effects of invasive tree species on the protective function of forests against rockfall in Switzerland and France: the case of Ailanthus altissima" and the Swiss Federal Office for the Environment (BAFU) project on "Risk reduction offered by protection forests". We further thank the reviewers for their valuable comments, which helped to improve earlier versions of the paper.

Edited by: T. Glade

Reviewed by: D. Toe and one anonymous referee

\section{References}

Abbruzzese, J. M., Sauthier, C., and Labiouse, V.: Considerations on Swiss methodologies for rock fall hazard mapping based on trajectory modelling, Nat. Hazards Earth Syst. Sci., 9, 10951109, doi:10.5194/nhess-9-1095-2009, 2009.

Agliardi, F. and Crosta, G. B.: High resolution three-dimensional numerical modelling of rockfalls, Int. J. Rock Mech. Min., 40, 455-471, doi:10.1016/S1365-1609(03)00021-2, 2003.

Agliardi, F., Crosta, G. B., and Frattini, P.: Integrating rockfall risk assessment and countermeasure design by 3D modelling techniques, Nat. Hazards Earth Syst. Sci., 9, 1059-1073, doi:10.5194/nhess-9-1059-2009, 2009.

Alila, Y., Kuraś, P. K., Schnorbus, M., and Hudson, R.: Forests and floods: A new paradigm sheds light on age-old controversies, Water Resour. Res., 45, W08416, doi:10.1029/2008WR007207, 2009. 
Berger, F. and Dorren, L. K.: Principles of the tool Rockfor.net for quantifying the rockfall hazard below a protection forest, Schweizerische Zeitschrift fur Forstwesen, 158, 157-165, doi:10.3188/szf.2007.0157, 2007.

Bigot, C., Dorren, L., and Berger, F.: Quantifying the protective function of a forest against rockfall for past, present and future scenarios using two modelling approaches, Nat. Hazards, 49, 99111, doi:10.1007/s11069-008-9280-0, 2009.

Bitterlich, W.: Die Winkelzählprobe, Allgemeine Forst- und Holzwirtschaftszeitung, 59, 4-5, 1948.

Borter, P., Heinimann, H. R., Bart, R., Egli, T., and Gächter, M.: Risikoanalyse bei gravitativen Naturgefahren: Methode, Umwelt-Materialien, 107/I, Bundesamt für Umwelt, BAFU, Bern, 117 pp., 1999.

Breiman, L., Friedman, J., Stone, C. J., and Olshen, R. A.: Classification and Regression Trees, Taylor \& Francis, 1984.

Budetta, P.: Assessment of rockfall risk along roads, Nat. Hazards Earth Syst. Sci., 4, 71-81, doi:10.5194/nhess-4-71-2004, 2004.

Cordonnier, T., Courbaud, B., Berger, F., and Franc, A.: Permanence of resilience and protection efficiency in mountain Norway spruce forest stands: A simulation study, Forest Ecol. Manag., 256, 347-354, doi:10.1016/j.foreco.2008.04.028, 2008.

Corominas, J. and Moya, J.: Contribution of dendrochronology to the determination of magnitude-frequency relationships for landslides, Geomorphology, 124, 137-149, doi:10.1016/j.geomorph.2010.09.001, 2010.

Corominas, J., Copons, R., Moya, J., Vilaplana, J. M., Altimir, J., and Amigó, J.: Quantitative assessment of the residual risk in a rockfall protected area, Landslides, 2, 343-357, doi:10.1007/s10346-005-0022-z, 2005.

Corominas, J., van Westen, C., Frattini, P., Cascini, L., Malet, J.-P., Fotopoulou, S., Catani, F., Van Den Eeckhaut, M., Mavrouli, O., Agliardi, F., Pitilakis, K., Winter, M. G., Pastor, M., Ferlisi, S., Tofani, V., Hervás, J., and Smith, J. T.: Recommendations for the quantitative analysis of landslide risk, B. Eng. Geol. Environ., 73, 209-263, doi:10.1007/s10064-013-0538-8, 2013.

Corona, C., Trappmann, D., and Stoffel, M.: Parameterization of rockfall source areas and magnitudes with ecological recorders: When disturbances in trees serve the calibration and validation of simulation runs, Geomorphology, 202, 33-42, doi:10.1016/j.geomorph.2013.02.001, 2013.

Dancey, C. P. and Reidy, J.: Statistics without maths for psychology, Fifth Edn., Pearson Education, 2011.

Dorren, L.: Rockyfor3D (v5.2) revealed - Transparent description of the complete 3D rockfall model, ecorisQ paper, Geneva, 32, www.ecorisq.org (last access: 20 February 2017), 2015.

Dorren, L. and Berger, F.: Stem breakage of trees and energy dissipation during rockfall impacts, Tree Physiol., 26, 63-71, 2005.

Dorren, L., Maier, B., Putters, U. S., and Seijmonsbergen, A. C.: Combining field and modelling techniques to assess rockfall dynamics on a protection forest hillslope in the European Alps, Geomorphology, 57, 151-167, doi:10.1016/S0169555X(03)00100-4, 2004.

Dorren, L. K. A., Berger, F., and Putters, U. S.: Real-size experiments and 3-D simulation of rockfall on forested and nonforested slopes, Nat. Hazards Earth Syst. Sci., 6, 145-153, doi:10.5194/nhess-6-145-2006, 2006.

Dorren, L., Berger, F., Jonsson, M., Krautblatter, M., Mölk, M., Stoffel, M., and Wehrli, A.: State of the art in rockfall - for- est interactions, Schweizerische Zeitschrift für Forstwesen, 158, 128-141, doi:10.3188/szf.2007.0128, 2007.

Dorren, L., Berger, F., Frehner, M., Huber, M., Kühne, K., Métral, R., Sandri, A., Schwitter, R., Thormann, J.-J., and Wasser, B.: Das neue NaiS-Anforderungsprofil Steinschlag, Schweizerische Zeitschrift für Forstwesen, 166, 16-23, doi:10.3188/szf.2015.0016, 2015.

Draper, N. R. and Smith, H.: Applied regression analysis, 3th Edn., Wiley series in probability and statistics, John Wiley \& Sons, Inc., 1998.

Dupire, S., Bourrier, F., Monnet, J.-M., Bigot, S., Borgniet, L., Berger, F., and Curt, T.: Novel quantitative indicators to characterize the protective effect of mountain forests against rockfall, Ecol. Indic., 67, 98-107, doi:10.1016/j.ecolind.2016.02.023, 2016.

Dussauge-Peisser, C., Helmstetter, A., Grasso, J.-R., Hantz, D., Desvarreux, P., Jeannin, M., and Giraud, A.: Probabilistic approach to rock fall hazard assessment: potential of historical data analysis, Nat. Hazards Earth Syst. Sci., 2, 15-26, doi:10.5194/nhess-2-15-2002, 2002.

Fuhr, M., Bourrier, F., and Cordonnier, T.: Protection against rockfall along a maturity gradient in mountain forests, Forest Ecol. Manag., 354, 224-231, doi:10.1016/j.foreco.2015.06.012, 2015.

Guzzetti, F., Reichenbach, P., and Wieczorek, G. F.: Rockfall hazard and risk assessment in the Yosemite Valley, California, USA, Nat. Hazards Earth Syst. Sci., 3, 491-503, doi:10.5194/nhess-3491-2003, 2003.

Hantz, D., Dussauge-Peisser, C., Jeannin, M., and Vengeon, J. M.: Rock fall hazard assessment: From qualitative to quantitative failure probability, Fast Slope Movements, Naples, 263-267, 2003.

Hantz, D., Ventroux, Q., Rossetti, J., and Berger, F..: A new approach of diffuse rockfall hazard, in: Landslides and Engineered Slopes, Experience, Theory and Practice, edited by: Aversa, S., Cascini, L., Picarelli, L., and Scavia, C., CRC Press, 1063-1067, 2016.

Hoffmann, T. and Schrott, L.: Modelling sediment thickness and rockwall retreat in an Alpine valley using 2D-seismic refraction (Reintal, Bavarian Alps), Z. Geomorph. Supp., 127, 153-173, 2002.

Hungr, O., Evans, S. G., and Hazzard, J.: Magnitude and frequency of rock falls and rock slides along the main transportation corridors of southwestern British Columbia, Can. Geotech. J., 36, 224-238, doi:10.1139/t98-106, 1999.

Jaboyedoff, M., Dudt, J. P., and Labiouse, V.: An attempt to refine rockfall hazard zoning based on the kinetic energy, frequency and fragmentation degree, Nat. Hazards Earth Syst. Sci., 5, 621-632, doi:10.5194/nhess-5-621-2005, 2005.

Jahn, J.: Entwaldung und Steinschlag, in: International Congress Interpraevent, Conference Proceedings, Interpraevent, Graz, 185198, 1988.

Kohavi, R.: A study of cross-validation and bootstrap for accuracy estimation and model selection, IJCAI'95 Proceedings of the 14th international joint conference on Artificial intelligence, Volume 2, 1137-1143, 1995.

Lan, H., Martin, C. D., Zhou, C., and Lim, C. H.: Rockfall hazard analysis using LiDAR and spatial modeling, Geomorphology, 118, 213-223, doi:10.1016/j.geomorph.2010.01.002, 2010. 
Lang, A., Moya, J., Corominas, J., Schrott, L., and Dikau, R.: Classic and new dating methods for assessing the temporal occurrence of mass movements, Geomorphology, 30, 33-52, doi:10.1016/S0169-555X(99)00043-4, 1999.

Lari, S., Frattini, P., and Crosta, G. B.: A probabilistic approach for landslide hazard analysis, Eng. Geol., 182, 3-14, doi:10.1016/j.enggeo.2014.07.015, 2014.

Lopez-Saez, J., Corona, C., Eckert, N., Stoffel, M., Bourrier, F., and Berger, F.: Impacts of land-use and landcover changes on rockfall propagation: Insights from the Grenoble conurbation, Sci. Total Environ., 547, 345-355, doi:10.1016/j.scitotenv.2015.12.148, 2016.

Lundström, T., Jonsson, M. J., Volkwein, A., and Stoffel, M.: Reactions and energy absorption of trees subject to rockfall: a detailed assessment using a new experimental method, Tree Physiol., 29, 345-359, doi:10.1093/treephys/tpn030, 2009.

Malamud, B. D., Turcotte, D. L., Guzzetti, F., and Reichenbach, P.: Landslide inventories and their statistical properties, Earth Surf. Proc. Land., 29, 687-711, doi:10.1002/esp.1064, 2004.

Maringer, J., Ascoli, D., Dorren, L., Bebi, P., and Conedera, M.: Temporal trends in the protective capacity of burnt beech forests (Fagus sylvatica L.) against rockfall, Eur. J. Forest Res., 135, 7488, doi:10.1007/s10342-016-0962-y, 2016.

Masuya, H., Amanuma, K., Nishikawa, Y., and Tsuji, T.: Basic rockfall simulation with consideration of vegetation and application to protection measure, Nat. Hazards Earth Syst. Sci., 9, 1835-1843, doi:10.5194/nhess-9-1835-2009, 2009.

McCarroll, D., Shakesby, R. A., and Matthews, J. A.: Enhanced rockfall activity during the Little Ice Age: further lichenometric evidence from a Norwegian talus, Permafrost Periglac., 12, 157-164, doi:10.1002/ppp.359, 2001.

McCullagh, P. and Nelder, J. A.: Generalized Linear Models, 2th Edn., Chapman \& Hall/CRC, London, 1989.

Messmer, C.: Grundflächen im Steinschlagschutzwald: Ein Vergleich mit LFI 3 Daten, MS, Institute for Terrestrial Ecosystems, Swiss Federal Institute of Technology, Zürich, 129 pp., 2014.

Moore, J. R., Sanders, J. W., Dietrich, W. E., and Glaser, S. D.: Influence of rock mass strength on the erosion rate of alpine cliffs, Earth Surf. Proc. Land., 34, 1339-1352, doi:10.1002/esp.1821, 2009.

Morel, P., Trappmann, D., Corona, C., and Stoffel, M.: Defining sample size and sampling strategy for dendrogeomorphic rockfall reconstructions, Geomorphology, 236, 79-89, doi:10.1016/j.geomorph.2015.02.017, 2015.

Moya, J., Corominas, J., Pérez Arcas, J., and Baeza, C.: Tree-ring based assessment of rockfall frequency on talus slopes at Solà d'Andorra, Eastern Pyrenees, Geomorphology, 118, 393-408, doi:10.1016/j.geomorph.2010.02.007, 2010.

Peila, D. and Guardini, C.: Use of the event tree to assess the risk reduction obtained from rockfall protection devices, Nat. Hazards Earth Syst. Sci., 8, 1441-1450, doi:10.5194/nhess-8-1441-2008, 2008.

Perret, S., Dolf, F., and Kienholz, H.: Rockfalls into forests: Analysis and simulation of rockfall trajectories - considerations with respect to mountainous forests in Switzerland, Landslides, 1, 123-130, doi:10.1007/s10346-004-0014-4, 2004.

Perret, S., Stoffel, M., and Kienholz, H.: Spatial and temporal rockfall activity in a forest stand in the Swiss Prealps - A den- drogeomorphological case study, Geomorphology, 74, 219-231, doi:10.1016/j.geomorph.2005.08.009, 2006.

Pfeiffer, T. and Bowen, T.: Computer simulation of rockfalls, Bulletin of the Association of Engineering Geologists, 26, 135-146, 1989.

Radtke, A., Toe, D., Berger, F., Zerbe, S., and Bourrier, F.: Managing coppice forests for rockfall protection - Lessons from modeling, Ann. For. Sci., 71, 485-494, doi:10.1007/s13595-013-0339z, 2014.

Rammer, W., Brauner, M., Ruprecht, H., and Lexer, M. J.: Evaluating the effects of forest management on rockfall protection and timber production at slope scale, Scand. J. Forest Res., 30, 719 731, doi:10.1080/02827581.2015.1046911, 2015.

Renaud, F. G., Sudmeier-Rieux, K., and Estrella, M. (Eds.): The role of ecosystems in disaster risk reduction, United Nations University, Tokyo, 486 pp., 2013.

Ripley, B., Therneau, T., and Atkinson, B.: Package "rpart", Ripley, Brian, 2015.

Romana, M., Seron, J. B., and Montalar, E. (Eds.): SMR Geomechanics classification: Application, experience and validation, South African Institute of Mining and Metallurgy, 4 pp., 2003.

Ruiz-Carulla, R., Corominas, J., and Mavrouli, O.: A methodology to obtain the block size distribution of fragmental rockfall deposits, Landslides, 12, 815-825, doi:10.1007/s10346-015-06007, 2015

Sass, O. and Wollny, K.: Investigations regarding Alpine talus slopes using ground-penetrating radar (GPR) in the Bavarian Alps, Germany, Earth Surf. Proc. Land., 26, 1071-1086, doi:10.1002/esp.254, 2001.

Sättele, M., Bründl, M., and Straub, D.: Quantifying the effectiveness of early warning systems for natural hazards, Nat. Hazards Earth Syst. Sci., 16, 149-166, doi:10.5194/nhess-16-149-2016, 2016.

Stahel, W.: Lineare Regression - Unterlagen zum Teil 1 des Kurses in Angewandter Regression: Seminar für Statistik, ETH Zürich, Zürich, 111 pp., 2013.

Stoffel, M. and Corona, C.: Dendroecological dating of geomorphic disturbance in trees, Tree-Ring Res., 70, 3-20, doi:10.3959/1536-1098-70.1.3, 2014.

Stoffel, M., Schneuwly, D., Bollschweiler, M., Lièvre, I., Delaloye, R., Myint, M., and Monbaron, M.: Analyzing rockfall activity (1600-2002) in a protection forest - a case study using dendrogeomorphology, Geomorphology, 68, 224-241, doi:10.1016/j.geomorph.2004.11.017, 2005.

Straub, D.: Natural hazards risk assessment using Bayesian networks, in: Proceedings ICOSSAR'05, edited by: Augusti, G., Schueller, G. I., and Ciampoli, M., 9th International Conference on Structural Safety and Reliability, Rome, 19-23 June, Millpress, Rotterdam, 2509-2516, 2005.

Straub, D. and Schubert, M.: Modeling and managing uncertainties in rock-fall hazards, Georisk: Assessment and Management of Risk for Engineered Systems and Geohazards, 2, 1-15, doi:10.1080/17499510701835696, 2008.

Trappmann, D. and Stoffel, M.: Counting scars on tree stems to assess rockfall hazards: A low effort approach, but how reliable?, Geomorphology, 180-181, 180-186, doi:10.1016/j.geomorph.2012.10.009, 2013. 
Trappmann, D. and Stoffel, M.: Visual dating of rockfall scars in Larix decidua trees, Geomorphology, 245, 62-72, doi:10.1016/j.geomorph.2015.04.030, 2015.

Trappmann, D., Stoffel, M., and Corona, C.: Achieving a more realistic assessment of rockfall hazards by coupling threedimensional process models and field-based tree-ring data, Earth Surf. Proc. Land., 39, 1866-1875, doi:10.1002/esp.3580, 2014.

Volkwein, A., Schellenberg, K., Labiouse, V., Agliardi, F., Berger, F., Bourrier, F., Dorren, L. K. A., Gerber, W., and Jaboyedoff, M.: Rockfall characterisation and structural protection - a review, Nat. Hazards Earth Syst. Sci., 11, 2617-2651, doi:10.5194/nhess-11-2617-2011, 2011.

Vorpahl, P., Elsenbeer, H., Märker, M., and Schröder, B.: How can statistical models help to determine driving factors of landslides?, Ecol. Model., 239, 27-39, doi:10.1016/j.ecolmodel.2011.12.007, 2012.
Wasser, B. and Perren, B.: Wirkung von Schutzwald gegen gravitative Naturgefahren - Protect-Bio, Schweizerische Zeitschrift für Forstwesen, 165, 275-283, doi:10.3188/szf.2014.0275, 2014.

Wehrli, A., Weisberg, P. J., Schönenberger, W., Brang, P., and Bugmann, H.: Improving the establishment submodel of a forest patch model to assess the long-term protective effect of mountain forests, Eur. J. Forest Res., 126, 131-145, doi:10.1007/s10342006-0142-6, 2006.

Whittow, J.: Dictionary of Physical Geography, Penguin, London, 1984. 